\title{
Advantages of New Endoscopic Unilateral Laminectomy for Bilateral Decompression (ULBD) over Conventional Microscopic ULBD
}

\author{
Hyeun-Sung Kim, MD, Sung-Hoon Choi, MD*, Dae-Moo Shim, $\mathrm{MD}^{\dagger}$, In-Seung Lee, $\mathrm{MD}^{\ddagger}$, \\ Young-Kwang $\mathrm{Oh}, \mathrm{MD}^{\S}$, Young-Ha Woo, $\mathrm{MD}^{\S}$ \\ Department of Neurosurgery, Gangnam Nanoori Hospital, Seoul, \\ * Department of Orthopaedic Surgery, Busan Bumin Hospital, Busan, \\ ${ }^{\dagger}$ Department of Orthopaedic Surgery, Pusan National University Yangsan Hospital, Yangsan, \\ ${ }^{\ddagger}$ Department of Orthopaedic Surgery, Wonkwang University Hospital, Iksan, \\ ${ }^{\S}$ Department of Orthopaedic Surgery, Daedong Hospital, Busan, Korea
}

Background: Biportal endoscopic unilateral laminectomy for bilateral decompression (ULBD) is an emerging minimally invasive procedure for spinal stenosis. However, reports of the results associated with this surgical method are still lacking.

Methods: We conducted a retrospective study of 60 patients who underwent bilateral decompression for lumbar central canal stenosis. The patients were divided into 2 groups according to the surgical method (endoscopic ULBD vs. microscopic ULBD). We compared the outcomes between the 2 groups in terms of postoperative segmental spinal instability, dura expansion, operation time, estimated blood loss, serum creatine kinase (CK), serum C-reactive protein (CRP), visual analog scale (VAS) score, Oswestry Disability Index (ODI), modified MacNab score, and the incidence of complications.

Results: The mean VAS, ODI, and modified MacNab score improved significantly from the preoperative period to the last follow-up in both groups and were better in the endoscopic ULBD group until the first day after treatment. The degree of horizontal displacement was lower in the endoscopic ULBD group than in the microscopic ULBD group at postoperative 12 months. Dura expansion, operation time, and estimated blood loss did not differ significantly between the 2 groups. Serum CK and CRP on the first day after treatment were lower in the endoscopic ULBD group than in the microscopic ULBD group.

Conclusions: This study shows that both endoscopic ULBD and microscopic ULBD can provide favorable outcomes for lumbar central canal stenosis. However, compared to microscopic ULBD, endoscopic ULBD has advantages in terms of postoperative segmental spinal instability, pain control, and serum CK and CRP.

Keywords: Spinal stenosis, Endoscopic ULBD, Microscopic ULBD, Postoperative spinal instability

Degenerative spinal stenosis is the most common indication for spine surgery in the elderly. ${ }^{1-3)}$ Degenerative changes including ligamentum flavum hypertrophy, facet

Received September 3, 2019; Accepted December 30, 2019

Correspondence to: Young-Ha Woo, MD

Department of Orthopaedic Surgery, Daedong Hospital, 187 Chungnyeoldaero, Dongnae-gu, Busan 47737, Korea

Tel: +82-51-554-1233, Fax: +82-51-553-7575

E-mail:woo0ha@naver.com joint hypertrophy, and intervertebral disc bulging cause nerve compression in the vertebral canal, intervertebral foramen, or lateral recess, resulting in dysfunction and impaired quality of life. ${ }^{2,4)}$ Several open surgical techniquesopen laminectomy with foraminotomy, partial facetectomy and microscopic unilateral laminectomy for bilateral decompression (ULBD), and endoscopic ULBD-have been introduced, but the optimal treatment method remains controversial. ${ }^{3,5,6)}$ Microscopic ULBD is a minimally invasive spinal canal decompression technique that mini- 
Kim et al. Advantages of New Endoscopic Unilateral Laminectomy for Bilateral Decompression

Clinics in Orthopedic Surgery • Vol. 12, No. 3, $2020 \bullet$ www.ecios.org

mizes any injury of the paravertebral muscle structures because it requires only unilateral exposure. ${ }^{7)}$ However, it may cause postoperative segmental spinal instability of the spine by posterior restraint failure due to an iatrogenic injury to the spine or its surrounding structures and may increase the risk of chronic back pain. ${ }^{8)}$ New endoscopic techniques using the unilateral biportal endoscopic approach for treating lumbar central canal spinal stenosis have received more spotlights recently., ${ }^{9,10)}$ Of those, endoscopic ULBD has several advantages, such as excellent magnification and illumination through a single portal as in spinal endoscopic surgery. Furthermore, compared to the conventional endoscopic surgery, it allows the surgeon to have a wider field of view and move the instrument freely. ${ }^{11)}$ However, reports of the clinical results associated with this surgical method are still lacking. To the best of our knowledge, this is the first report since the introduction of endoscopic ULBD, comparing its clinical outcomes with those of microscopic ULBD.

\section{METHODS}

We performed a retrospective study of 60 consecutive patients who underwent bilateral decompression of the lumbar central canal stenosis between September 2015 and March 2017. Thirty patients underwent microscopic ULBD from September 2015 to August 2016 and another 30 patients underwent endoscopic ULBD from August 2016 to March 2017. The above 2 groups were divided not by medical criteria but by surgeon's preference. Since August 2016, assuming that endoscopic ULBD would have many advantages over microscopic ULBD, we have performed endoscopic ULBD mostly except for cases that inevitably require microscopic ULBD. The inclusion criteria were central canal spinal stenosis with intermittent neurologic claudication or radicular leg pain refractory to conservative treatment. Patients who underwent concomitant fusion or instrumentation placement, patients who had previously undergone lumbar surgery at the same level, patients who underwent lumbar laminectomy with discectomy, and patients with any grade of spondylolisthesis or degenerative scoliosis on dynamic radiographs were excluded. Patients with abnormal C-reactive protein (CRP) and serum creatine kinase $(\mathrm{CK})$ preoperatively were also excluded. The study was approved by the Institutional Review Board of Daedong Hospital (IRB No. 2019-02), and written informed consent was obtained from all patients. Data were obtained using the electronic patient record and patient management questionnaire. The questionnaire was sent to patients with a letter explaining the purpose of the questionnaire and the role of the participant. Data were collected from preoperatively to 12 months postoperatively. Radiologic outcomes including horizontal displacement and dura expansion were evaluated using dynamic roentgenograms and magnetic resonance imaging (MRI) respectively. Horizontal displacement (Fig. 1) was assessed on X-rays obtained in standing flexion/extension preoperatively and 12 months postoperatively, and anterior translation was also assessed. ${ }^{12)}$ Dura expansion was calculated with axial cuts of preoperative and postoperative T2-weighted MRI. The results were evaluated by the area calculation program of a picture archiving and communication system (INFINIT PACS, Seoul, Korea). Clinical outcomes were quantified using the back and leg visual analog scale (VAS; 0-10), modified MacNab criteria (excellent, good, fair, and poor), and Oswestry Disability Index (ODI; 0\%-100\%) at 1-week, 1-month, 3-month, and 1 -year follow-ups. Based on video records of endoscopic and microscopic surgery, operative time was calculated from the incision to the end of the decompression, excluding time to wound closure. Other perioperative data (estimated blood loss, serum CK, CRP, complications) were evaluated using clinical lab values and clinical charts. ${ }^{13)}$ Statistical analysis was performed by chi-square test and independent sample $t$-test using IBM SPSS ver. 22.0 (IBM Corp., Armonk, NY, USA). A p-value less than 0.05 was considered statistically significant.

\section{RESULTS}

Sixty patients who underwent spinal surgery were included in this study: 30 patients in the endoscopic ULBD

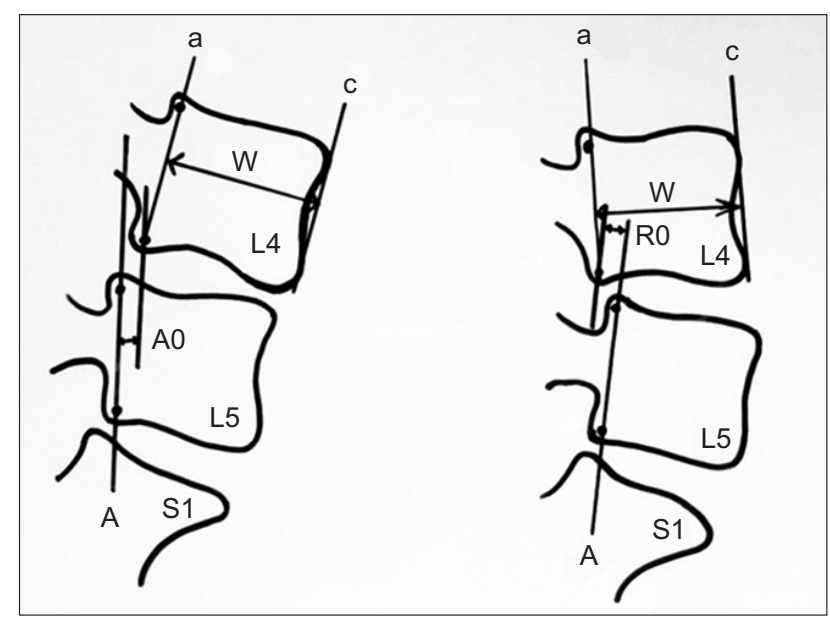

Fig. 1. Horizontal displacement $(H D)$ is anterolisthesis $(A 0)$ or retrolisthesis $(\mathrm{RO})$ over the mid-body width of the upper vertebrae. $\mathrm{HD}(\%)=(\mathrm{A} 0$ or $\mathrm{RO})$ $/ \mathrm{W} \times 100$. 
Kim et al. Advantages of New Endoscopic Unilateral Laminectomy for Bilateral Decompression

Clinics in Orthopedic Surgery • Vol. 12, No. 3, $2020 \bullet$ www.ecios.org

group and 30 patients in the microscopic ULBD group. The demographic and preoperative characteristics of the patients were not statistically different (Table 1). The radiologic outcomes, surgical data, and laboratory results are shown in Table 2 and clinical outcomes are shown in Table 3. The degree of horizontal displacement was lower in the endoscopic ULBD group than in the microscopic ULBD group $(0.28 \% \pm 0.27 \%$ vs. $2.92 \% \pm 1.82 \%, p<0.001)$ (Fig. $2 \mathrm{~A})$. Postoperative pain and ODI expressed in percentage were significantly improved in both groups $(p<0.001)$. There was a significant difference in the improvement of pain (VAS) at 1 week after operation between the endoscopic ULBD group and the microscopic ULBD group $(38.37 \% \pm 4.40 \%$ vs. $52.50 \% \pm 7.95 \%, p=0.00)$ (Fig. $2 \mathrm{~B})$. There was a significant difference in the improvement of ODI at 1 week after operation between the endoscopic ULBD group and the microscopic ULBD group (38.37 \pm 4.40 vs. $52.50 \pm 7.95, p=0.00$ ) (Fig. 2 C). However, there was no significant difference in ODI at 1 month after operation and 1 year after operation in both groups. There was a significant difference in the modified MacNab score at 1 week after operation between the endoscopic ULBD group and the microscopic ULBD group (83.33\% vs. $66.66 \%, p=0.00$ ) (Fig. $2 \mathrm{D}$ ). There was no significant difference in the modified MacNab score expressed in percentage from 1 month after operation to 1 year after

\section{Table 1. Demographic and Preoperative Patient Data}

\begin{tabular}{|c|c|c|c|}
\hline Characteristic & $\begin{array}{l}\text { Endoscopic } \\
\text { ULBD }\end{array}$ & $\begin{array}{l}\text { Microscopic } \\
\text { ULBD }\end{array}$ & $p$-value \\
\hline Age (yr) & $64.23 \pm 5.26$ & $66.20 \pm 6.01$ & 0.18 \\
\hline Sex (male : female) & $13(43.3)$ : $17(56.7) 1$ & 2 (40.0) : $18(60.0)$ & 0.07 \\
\hline Symptom duration (wk) & $13.07 \pm 4.51$ & $12.40 \pm 4.28$ & 0.56 \\
\hline Level treated & & & 0.78 \\
\hline $\mathrm{L} 2 / 3$ & $2(6.7)$ & $4(13.3)$ & \\
\hline L3/4 & $8(26.7)$ & $8(26.7)$ & \\
\hline$\llcorner 4 / 5$ & $18(60.0)$ & $16(53.3)$ & \\
\hline L5/S1 & $2(6.7)$ & $2(6.7)$ & \\
\hline \multicolumn{4}{|l|}{ Symptom (\%) } \\
\hline Low back pain & $25(83.3)$ & $27(90.0)$ & 0.58 \\
\hline Radiculopathy & $18(60.0)$ & $20(66.7)$ & 0.29 \\
\hline $\begin{array}{l}\text { Cross sectional area } \\
\left(\mathrm{mm}^{2}\right) \text { of thecal sac } \\
\text { (preoperative) }\end{array}$ & $372.48 \pm 73.86$ & $388.72 \pm 93.14$ & 0.38 \\
\hline
\end{tabular}

Values are presented as mean \pm standard deviation or number (\%). ULBD: unilateral laminectomy for bilateral decompression. operation. There was no significant difference in dura expansion (329.71 \pm 54.21 vs. $315.20 \pm 62.79, p=0.15$ ) (Fig.

\begin{tabular}{|c|c|c|c|}
\hline Variable & $\begin{array}{c}\text { Endoscopic } \\
\text { decompression }\end{array}$ & $\begin{array}{l}\text { Microscopic } \\
\text { decompression }\end{array}$ & $p$-value \\
\hline Horizontal displacement (\%) & $0.28 \pm 0.27$ & $2.92 \pm 1.82$ & $<0.001$ \\
\hline Dura expansion $\left(\mathrm{mm}^{2}\right)$ & $329.71 \pm 54.21$ & $315.20 \pm 62.79$ & 0.15 \\
\hline $\begin{array}{l}\text { CK (mg/dL; postoperative } \\
2 \text { day) }\end{array}$ & $130.87 \pm 51.49$ & $331.40 \pm 118.09$ & $<0.001$ \\
\hline $\begin{array}{l}\text { CRP (mg/dL; postoperative } \\
2 \text { day) }\end{array}$ & $2.36 \pm 1.09$ & $5.92 \pm 1.34$ & $<0.001$ \\
\hline $\begin{array}{l}\mathrm{CRP}(\mathrm{mg} / \mathrm{dL} ; \text { postoperative } \\
1 \mathrm{wk})\end{array}$ & $0.62 \pm 0.38$ & $0.85 \pm 0.67$ & 0.12 \\
\hline Operation time (min) & $58.10 \pm 6.04$ & $62.43 \pm 8.09$ & 0.02 \\
\hline Mean blood loss (mL) & $53.63 \pm 10.08$ & $59.47 \pm 11.88$ & 0.04 \\
\hline
\end{tabular}

CK: creatine kinase, CRP: C-reactive protein.

Table 3. Comparison of Clinical Outcomes between Endoscopic Decompression and Microscopic Decompression

Variable $\quad \begin{array}{cc}\text { Endoscopic } & \text { Microscopic } \\ \text { decompression } & \text { decompression }\end{array}$

Visual analog scale

\begin{tabular}{|lccc} 
Preoperative & $7.13 \pm 0.86$ & $7.27 \pm 0.83$ & 0.54 \\
\hline Postoperative (1 wk) & $1.87 \pm 0.82$ & $3.70 \pm 0.75$ & $<0.001$ \\
\hline Postoperative (1 mo) & $1.53 \pm 0.63$ & $1.77 \pm 0.73$ & 0.19 \\
\hline Postoperative (3 mo) & $1.37 \pm 0.49$ & $1.47 \pm 0.68$ & 0.52 \\
\hline Postoperative (1 yr) & $1.23 \pm 0.43$ & $1.27 \pm 0.45$ & 0.77
\end{tabular}

Oswestry Disability Index (\%)

\begin{tabular}{|c|c|c|c|}
\hline Preoperative & $71.20 \pm 4.29$ & $72.00 \pm 6.22$ & 0.56 \\
\hline Postoperative (1 wk) & $38.37 \pm 4.40$ & $52.50 \pm 7.95$ & $<0.001$ \\
\hline Postoperative (1 mo) & $27.70 \pm 2.51$ & $27.60 \pm 5.85$ & 0.93 \\
\hline Postoperative (3 mo) & $26.27 \pm 3.48$ & $26.47 \pm 5.07$ & 0.86 \\
\hline Postoperative (1 yr) & $23.53 \pm 3.51$ & $24.70 \pm 5.22$ & 0.31 \\
\hline \multicolumn{4}{|c|}{ Modified MacNab score (\%) } \\
\hline Postoperative (1 wk) & 83.33 & 66.66 & $<0.001$ \\
\hline Postoperative (1 mo) & 83.33 & 76.66 & $<0.001$ \\
\hline Postoperative (3 mo) & 80.00 & 76.66 & $<0.001$ \\
\hline Postoperative (1 yr) & 76.66 & 73.33 & $<0.001$ \\
\hline
\end{tabular}


Kim et al. Advantages of New Endoscopic Unilateral Laminectomy for Bilateral Decompression Clinics in Orthopedic Surgery • Vol. 12, No. 3, $2020 \bullet$ www.ecios.org$$
\text { 翼 }
$$

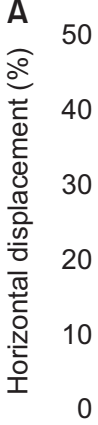

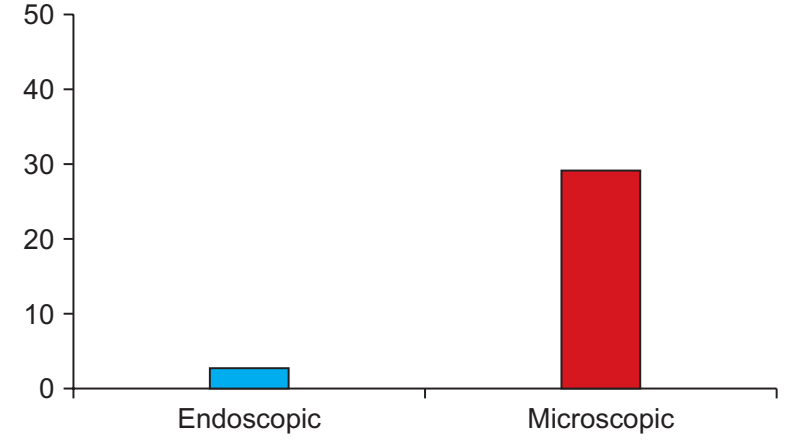

C

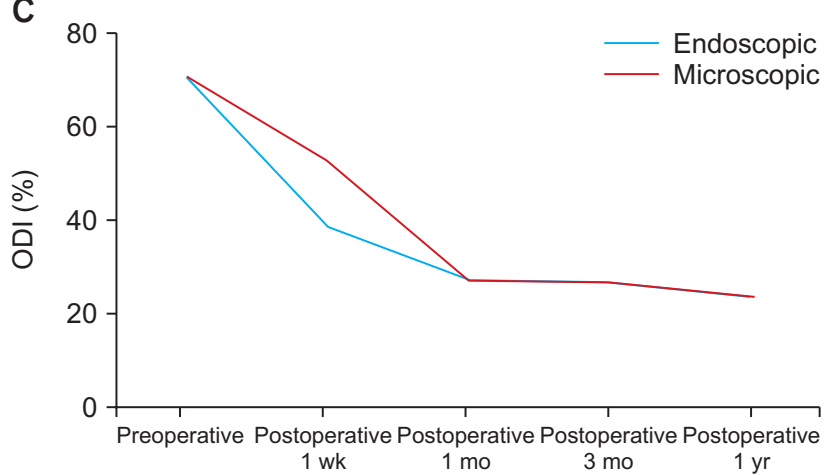

E

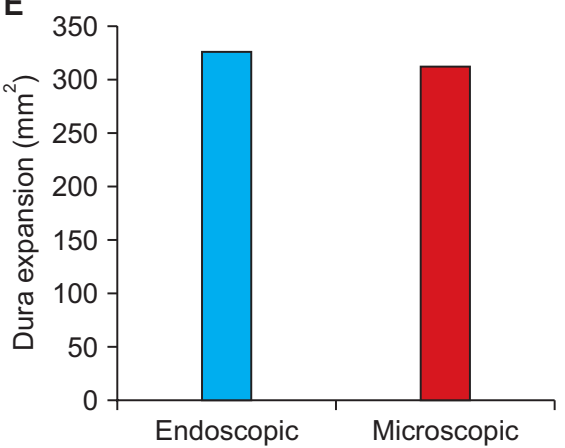

$\mathrm{H}$

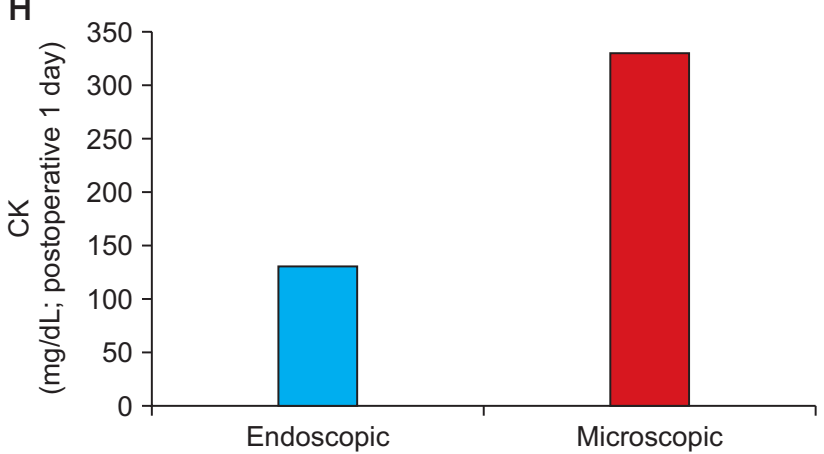

B

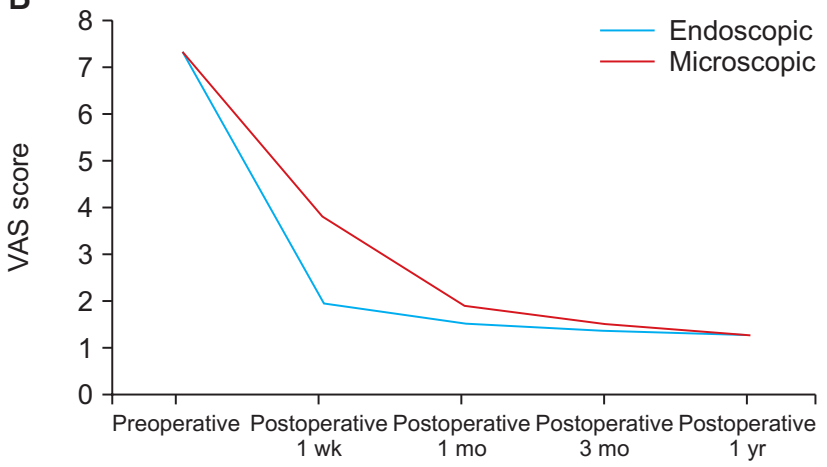

.

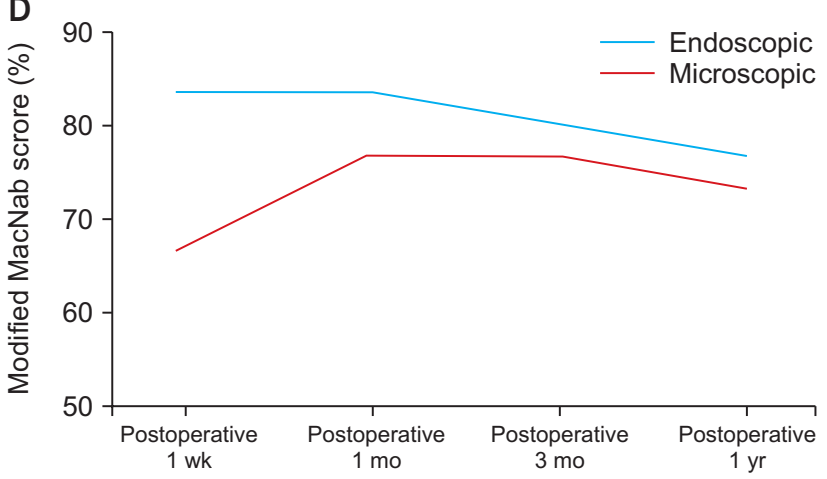

G

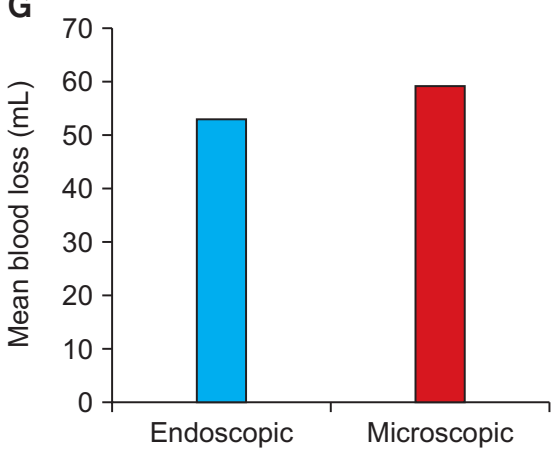

I

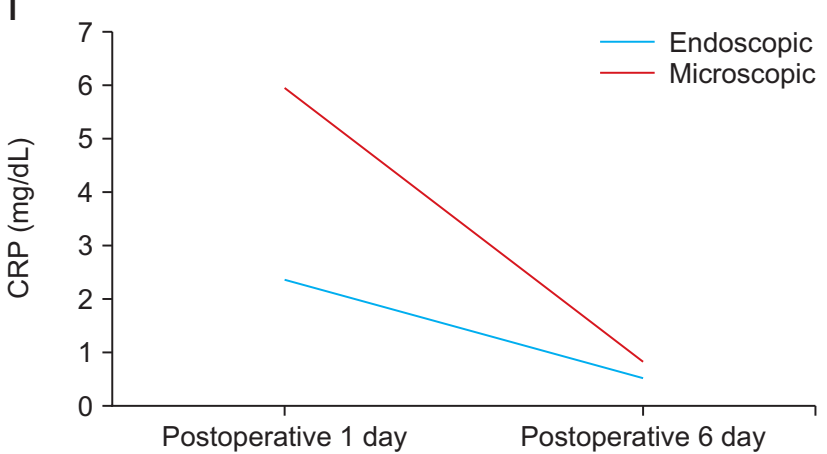

Fig. 2. The radiologic outcomes, surgical data, and laboratory results. (A) Horizontal displacement. (B) Visual analog scale (VAS) scores. (C) Oswestry Disability Index (ODI). (D) Modified MacNab scrores. (E) Dura expansion. (F) Operation time. (G) Mean blood loss. (H) Serum creatine kinase (CK). (I) Serum C-reactive protein (CRP).

$2 \mathrm{E})$ and operation time $(58.10 \pm 6.04$ vs. $62.43 \pm 8.09, p$ $=0.25)($ Fig. $2 \mathrm{~F}$ ) between 2 groups. The estimated blood loss was not significantly different between the 2 groups
$(53.63 \pm 10.08$ vs. $59.47 \pm 11.88, p=0.04)$ (Fig. $2 \mathrm{G})$. Serum $\mathrm{CK}$ and CRP on the first day after operation were lower in the endoscopic ULBD group than in the microscopic 
Kim et al. Advantages of New Endoscopic Unilateral Laminectomy for Bilateral Decompression

Clinics in Orthopedic Surgery • Vol. 12, No. 3, $2020 \bullet$ www.ecios.org

ULBD group (CK: $130.87 \pm 51.49$ vs. $331.40 \pm 118.09, p=$ 0.00 ; CRP: $2.36 \pm 1.09$ vs. $5.92 \pm 1.34, p=0.12$ ) (Fig. $2 \mathrm{H}$ and I). However, serum CRP at 6 days after operation was not significantly different between the 2 groups ( $0.62 \pm$ 0.38 vs. $0.85 \pm 0.67, p=0.12$ ) (Fig. 2I). Preoperative and postoperative MRI and endoscope images obtained from a patient with lumbar central canal stenosis treated with endoscopic ULBD are shown in Fig. 3. There were 2 cases of cerebrospinal fluid leak in the microscopic ULBD group and 1 case in the endoscopic ULBD group, all of which were treated with conservative treatment including bed rest and fluid replacement. Surgical site infection occurred in 1 case in the microscopic ULBD group and was treated with third-generation cephalosporin antibiotics.

\section{DISCUSSION}

Although the conventional open laminectomy is a standard effective treatment for lumbar central canal stenosis, open surgery may have an adverse effect on anatomical support tissues such as muscles or ligaments and cause surgical damage to surrounding tissues, which may lead to postoperative back pain and muscle atrophy. ${ }^{14,15)}$ In addition, postoperative spinal instability occurs in an operated intervertebral level after extensive decompression or at a level adjacent to the fused one. Decompressive surgery leads to muscular and ligamentous damage and any bone
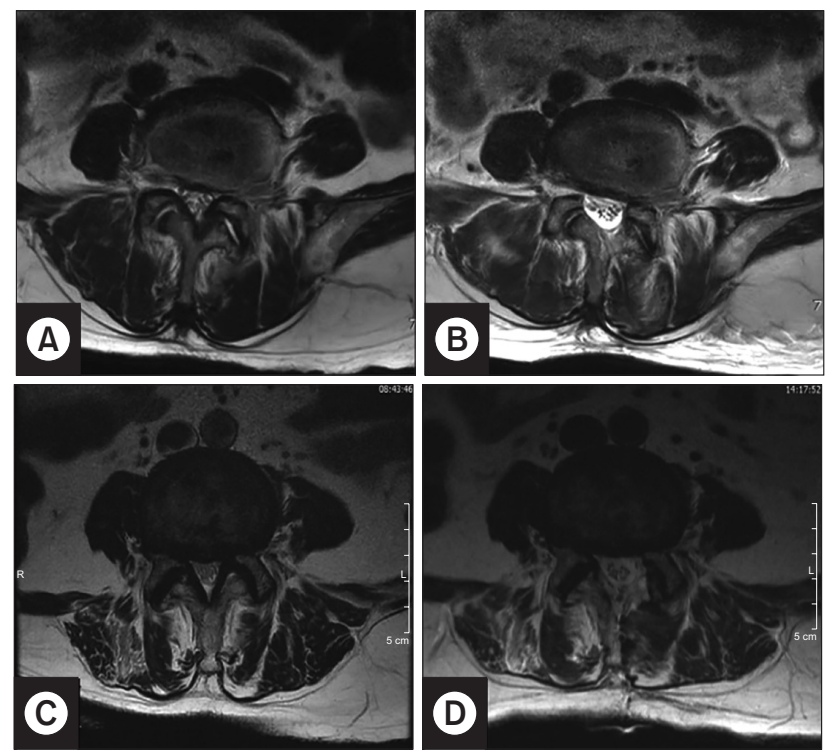

Fig. 3. Preoperative $(A, C)$ and postoperative $(B, D) T 2$-weighted magnetic resonance images obtained in patients who underwent $L 4 / 5$ decompression. The top row is a case of endoscopic laminectomy and the bottom row is a case of microscopic laminectomy. removal impairs stability at the operated levels. Spinal fusion has been shown to produce stress on the adjacent cephalad or caudal unfused segments, which displaces the center of rotation of the lumbar spine in a cephalad and posterior direction. ${ }^{12)}$ As a result, postoperative segmental spinal instability after decompression surgery may cause pain and necessitate additional fusion surgery. ${ }^{4}$ In order to overcome these drawbacks, minimally invasive surgical techniques have been developed to reduce the damage to surrounding tissues. ${ }^{4,14,16)}$

Microscopic ULBD performed for degenerative lumbar central canal stenosis has produced favorable results. However, this approach is disadvantageous in that it requires muscle incision and it is difficult to obtain the opposite view in patients with obesity or significant muscular development. In addition, the microscopic ULBD approach may require extensive laminectomy and adjustment of the patient's position to decompress the contralateral traversing nerve root during surgery, since both the view of the surgeon beyond the spinal canal and the operating range of the surgical instrument are limited. ${ }^{9)}$

Recently, single-portal endoscopic decompression has been attempted. ${ }^{17)}$ However, since many surgeons are not yet familiar with the single-portal endoscopic approach, inadequate decompression may occur.

Endoscopic ULBD combines the advantages of the standard open surgery and endoscopic spinal surgery. This operation is a fusion and modification of translaminar endoscopic decompression and microscopic unilateral laminectomy. The endoscopic decompression approach allows the surgeon to view the surgical site at high magnification and to view the contralateral, sublaminar, and foraminal areas as well. The advantages of endoscopic ULBD is that the surgical view is similar to that of the microscopic ULBD. And continuous pressure saline irrigation reduces bleeding and facilitates bilateral foraminal decompression. Further, by tilting the working portal, the surgeon can perform similar volume decompression with less posterior facet violation. Endoscopic ULBD system uses an independent channel for the surgical instrument, so movement is not restricted. In addition, it is possible to view the spine from various angles using a $0^{\circ}$ or $30^{\circ}$ arthroscope. And the endoscopic view is the same as that of the conventional surgery. So experienced spine surgeons can learn surgical techniques of endoscopic ULBD without difficulty. ${ }^{18)}$

In the operation of patients with a pathologic lesion on their right side, the working portal is located at the surgeon's left side. So, it is difficult to control bleeding and instrument without use of both hands, and the operation time may be longer. However, experienced surgeons 
Kim et al. Advantages of New Endoscopic Unilateral Laminectomy for Bilateral Decompression

Clinics in Orthopedic Surgery • Vol. 12, No. 3, $2020 \bullet$ www.ecios.org

can reduce the operation time by switching 2 portals. Our results showed that there was no significant difference in operating time between the endoscopic ULBD and microscopic ULBD groups.

In this study, endoscopic ULBD showed some advantages as a form of minimally invasive spine surgery. The results of this study were as follows: first, the increment of horizontal displacement was lower in the endoscopic ULBD group than in the microscopic ULBD group, which demonstrates that endoscopic ULBD reduces secondary postoperative segmental spinal instability after surgery. Second, pain (VAS), quality of life (ODI), and patient satisfaction (modified $\mathrm{MacNab}$ ) improved significantly in a short-term period after endoscopic ULBD compared to those after microscopic ULBD. The serum CK and CRP on the first day after endoscopic ULBD were elevated less than those after microscopic ULBD. Although muscle damage during surgery is difficult to directly assess quantitatively, the serum CK has been used as a suitable parameter for evaluating muscle damage in a variety of spinal operations. In previous studies, the CK level was significantly correlated with the length and depth of surgical incision, ${ }^{19)}$ and there was a significant relationship between the serum enzyme level and the duration and intensity of pressure on the paraspinal muscle induced by retraction. ${ }^{20-22)}$ Based on these findings, we could indirectly assess the degree of muscle damage with serum CK. Thus, compared to microscopic ULBD, endoscopic ULBD may provide improved clinical outcomes by reducing tissue damage.

Limitations of this study include the retrospective study design, small sample size, and short follow-up period. In addition, owing to the nature of the retrospective study, there was a risk of selection bias, and the surgeon's experience may have affected the outcomes. However, our findings indicate that endoscopic ULBD may be a viable alternative to microscopic ULBD based on good clinical results and the convenience of new endoscopic equipment. Further randomized prospective studies on endoscopic ULBD are needed to validate our outcomes.

This study shows that both endoscopic and microscopic ULBD can be effective treatments for patients with lumbar stenosis, especially the central canal type. However, endoscopic ULBD can be a superior procedure in terms of preventing postoperative segmental instability and causing less postoperative pain. Therefore, endoscopic ULBD could be an alternative surgical procedure for treating central canal spinal stenosis.

\section{CONFLICT OF INTEREST}

No potential conflict of interest relevant to this article was reported.

\section{REFERENCES}

1. Cavusoglu H, Kaya RA, Turkmenoglu ON, Tuncer C, Colak I, Aydin Y. Midterm outcome after unilateral approach for bilateral decompression of lumbar spinal stenosis: 5-year prospective study. Eur Spine J. 2007;16(12):2133-42.

2. Rosen DS, O’Toole JE, Eichholz KM, et al. Minimally invasive lumbar spinal decompression in the elderly: outcomes of 50 patients aged 75 years and older. Neurosurgery. 2007;60(3):503-9.

3. Turner JA, Ersek M, Herron L, Deyo R. Surgery for lumbar spinal stenosis: attempted meta-analysis of the literature. Spine (Phila Pa 1976). 1992;17(1):1-8.

4. Costa F, Sassi M, Cardia A, et al. Degenerative lumbar spinal stenosis: analysis of results in a series of 374 patients treated with unilateral laminotomy for bilateral microdecompression. J Neurosurg Spine. 2007;7(6):579-86.

5. Ji YC, Kim YB, Hwang SN, Park SW, Kwon JT, Min BK. Efficacy of unilateral laminectomy for bilateral decompression in elderly lumbar spinal stenosis. J Korean Neurosurg Soc. 2005;37(6):410-5.
6. Lee JH, Choi KC, Shim HK, Shin SH, Lee DC. Percutaneous biportal endoscopic surgery for lumbar degenerative diseases. J Minim Invasive Spine Surg Techn. 2017;2(1):15-9.

7. Phan K, Teng I, Schultz K, Mobbs RJ. Treatment of lumbar spinal stenosis by microscopic unilateral laminectomy for bilateral decompression: a technical note. Orthop Surg. 2017;9(2):241-6.

8. Carragee EJ, Han MY, Suen PW, Kim D. Clinical outcomes after lumbar discectomy for sciatica: the effects of fragment type and anular competence. J Bone Joint Surg Am. 2003;85(1):102-8.

9. Hwa Eum J, Hwa Heo D, Son SK, Park CK. Percutaneous biportal endoscopic decompression for lumbar spinal stenosis: a technical note and preliminary clinical results. J Neurosurg Spine. 2016;24(4):602-7.

10. Soliman HM. Irrigation endoscopic discectomy: a novel percutaneous approach for lumbar disc prolapse. Eur Spine J. 2013;22(5):1037-44.

11. Choi DJ, Choi CM, Jung JT, Lee SJ, Kim YS. Learning 
Kim et al. Advantages of New Endoscopic Unilateral Laminectomy for Bilateral Decompression

Clinics in Orthopedic Surgery • Vol. 12, No. 3, $2020 \bullet$ www.ecios.org

curve associated with complications in biportal endoscopic spinal surgery: challenges and strategies. Asian Spine J. 2016;10(4):624-9.

12. Alam WC. Radiological evaluation of lumbar intervertebral instability. Ind J Aerospace Med. 2002;46(2):48-53.

13. Wu WC, Smith TS, Henderson WG, et al. Operative blood loss, blood transfusion, and 30-day mortality in older patients after major noncardiac surgery. Ann Surg. 2010;252(1):11-7.

14. Mobbs RJ, Li J, Sivabalan P, Raley D, Rao PJ. Outcomes after decompressive laminectomy for lumbar spinal stenosis: comparison between minimally invasive unilateral laminectomy for bilateral decompression and open laminectomy: clinical article. J Neurosurg Spine. 2014;21(2):179-86.

15. Hu ZJ, Fang XQ, Zhou ZJ, Wang JY, Zhao FD, Fan SW. Effect and possible mechanism of muscle-splitting approach on multifidus muscle injury and atrophy after posterior lumbar spine surgery. J Bone Joint Surg Am. 2013;95(24):e192.

16. Poletti CE. Central lumbar stenosis caused by ligamentum flavum: unilateral laminotomy for bilateral ligamentectomy: preliminary report of two cases. Neurosurgery. 1995;37(2):343-7.
17. Sairyo K, Sakai T, Higashino K, Inoue M, Yasui N, Dezawa A. Complications of endoscopic lumbar decompression surgery. Minim Invasive Neurosurg. 2010;53(4):175-8.

18. Choi CM, Chung JT, Lee SJ, Choi DJ. How I do it? Biportal endoscopic spinal surgery (BESS) for treatment of lumbar spinal stenosis. Acta Neurochir (Wien). 2016;158(3):459-63.

19. Kawaguchi Y, Matsui H, Tsuji H. Back muscle injury after posterior lumbar spine surgery: a histologic and enzymatic analysis. Spine (Phila Pa 1976). 1996;21(8):941-4.

20. Arts MP, Nieborg A, Brand R, Peul WC. Serum creatine phosphokinase as an indicator of muscle injury after various spinal and nonspinal surgical procedures. J Neurosurg Spine. 2007;7(3):282-6.

21. Kumbhare D, Parkinson W, Dunlop B. Validity of serum creatine kinase as a measure of muscle injury produced by lumbar surgery. J Spinal Disord Tech. 2008;21(1):49-54.

22. Motosuneya T, Asazuma T, Tsuji T, Watanabe H, Nakayama Y, Nemoto K. Postoperative change of the cross-sectional area of back musculature after 5 surgical procedures as assessed by magnetic resonance imaging. J Spinal Disord Tech. 2006;19(5):318-22. 